\title{
The Influence of Using Academic Information System on Private University Image and Its Impact to Competitive Advantage
}

\author{
Realize \\ University of 17 Agustus 1945 Surabaya \\ Ida Aju Brahmasari \\ University of 17 Agustus 1945 Surabaya \\ Hotman Panjaitan \\ University of 17 Agustus 1945 Surabaya
}

\begin{abstract}
Competition among colleges in getting new students is getting fiercer. They are required to be able to have competitive advantages through improving facilities and image of the college to students and candidate students. The population in this research is students who are at least in the second year and come from private universities that have used academic information system. This study uses structural Equation Modeling (SEM) with AMOS version 22 are applied as tools in analyzing data. The results of research drawn based on hypothesis analysis and some tests show that academic information system has a significant influence on the image directly and indirectly to the competitive advantage of private universities in Kepulauan Riau province. This shows that by using Academic Information System, the students are very helpful in lecture activities because it provides a good assessment on the college which will finally give good appraisal of the competitive advantage of private universities in Kepulauan Riau province.
\end{abstract}

Keywords: academic information system, image, competitive advantage, private university

\section{INTRODUCTION}

Competition in the environment of higher education, is something must be observed and viewed from various point of views to maximize competitive advantage. Universities must be able to face the challenges of globalization and pass graduates who can compete in the community. Kepulauan Riau province as one of the newest provinces in Indonesia, in this year has owned 2 states and 56 private universities. Competition occurs not only among local private universities, and private universities against state universities in Kepulauan Riau but also among private universities in Indonesia even with universities from neighboring countries as well. This has an impact on the increasing difficulty of universities to maintain the exited number of students and obtain new students in each year. A fact the survival of private universities in Indonesia still depends on the number of student enrollment.

Currently the competition among universities in recruiting new students is increasing. According Assauri that the competitive advantage of a company from its competitors can be generated from technological sophistication or from the distribution network owned by the company [1]. In addition, people are more intelligent in choosing educational institutions. The college's big names became one of their other considerations in making choices other are the facilities which are provided by the college. A good image or reputation will get a greater appraisal for positive surprises and smaller market penalties for negative surprises than any other company [14]. 


\section{Marketing Services}

\section{LITERATURE REVIEW}

Lupiyoadi states that the marketing of services is any action offered by one of the parties which is principally intangible and does not cause any transfer of ownership [11]. Service marketing has become a major part of current economic activity. One of them is in the education sector conducted by universities. Based on the World Trade Organization (WTO) classification, in accordance with GATS / WTO-Central Product Classification / MTN.GNS / W / 120, education services are included in one of the service business classifications. Lupiyoadi states that there are some characteristics of services at universities [11]:

○ Colleges belong to pure service groups, where the provision of services is supported by work tools or supporting facilities only.

- Services provided require the presence of service users (students), in this case students who come to the institution of Education get the desired services.

- High contract system. The customer must be part of the service system.

○ Relationships with customers based on membership relationship.

\section{Academic Information System}

According to Hardcastle a system can be defined as a collection of components that work together toward a common goal [8]. The purpose of a system is to accept, input and convert them into outputs. The same thing was also stated by Ramachandra et al. which states that a system is a collection of elements which are combined to achieve a common goal [16]. A system is group of elements that are set with a specific purpose. Information is data that is processed, useful or relevant data, data with surprise value, useful data in the decision making process [24].

Systems using modern technology can provide information for users in easy format to understand that they are enable to use information systems effectively and improve their performance, high quality systems lead to high information quality. High quality information helps the Organization manage their business processes, make decisions, and improve organizational performance [2]. The utilization of systems in routine activities is the level and manner in which staff and customers utilize the capabilities of information systems [13]. The role of information systems will be regarded as one of the most important actions and achieving overall success will depend on user satisfaction [21]. This is also supported by Petter and Mclean in his research stating that user or user satisfaction is a harbinger of Consent or compatibility and user satisfaction with the production of information systems [12].

A Management Information System is defined as a computer-based system that makes information available for users with similar needs [17]. Academic information system is one of the implementation of management information system commonly used today in college. Raymond and Bergeron said that the quality of information output by the Performance Management Information System (PMIS) is closely related to the technical aspects and system services, namely system quality [18]. According to Hasan et al. there is a significant relationship between system quality and information quality [9].

\section{Image}

Image is a series of tangible and intangible characteristic such as the ideas, beliefs, values, interests and features that make them unique [9]. The image is the impression which is achieved from knowledge and understanding of facts or reality [4]. The image is formed based on knowledge and information received by someone. Image shows the impression of an object 
toward another object formed in processing information every time from various reliable sources in accordance with one's knowledge and experience about something [3].

\section{Competitive Advantages}

Competitive Advantage is a real step in the selection and implementation of a common strategy to achieve and maintain its superiority [15]. Besanko et al state that the competitive advantage of a company is when a company gets a higher profit economically than the average profit of another company competing in the same market [6].

Robbins \& Coulter defines competitive advantage as distinguishing factors or different edge of a company [19]. They both associate competitive advantage with core competencies. The competitive advantage of an organization is not only determined by external factors but also internal sources covering various areas. The concept of competitive advantage is manifested through appropriate management actions while managing the structures, processes, cultures and people of an organization [23]. Assauri agrees that the competitive advantage of an enterprise from its competitors can be generated from technological sophistication or from the company's distribution network [5].

\section{RESEARCH METHOD}

The population in this study are students who come from private universities in the province of Kepulauan Riau who have used academic information system. The samples were drown by using proportional random sampling technique from the active students who are at least have been at semester 5. Data collection technique used was the distribution of questionnaires filled out by 381 respondents. The samples calculated based non Slovin formula with a tolerance of $5 \%[20]$.

All variables are rated on a five-point Likert scale from strongly agree to strongly disagree. Confirmatory factor analysis is used to test the goodness of fit of the data set. To assess the effect of academic information system and image on competitive advantage, structural equation modeling by using amos software version 22 . The structural model of the variables measured in this study are as follows:

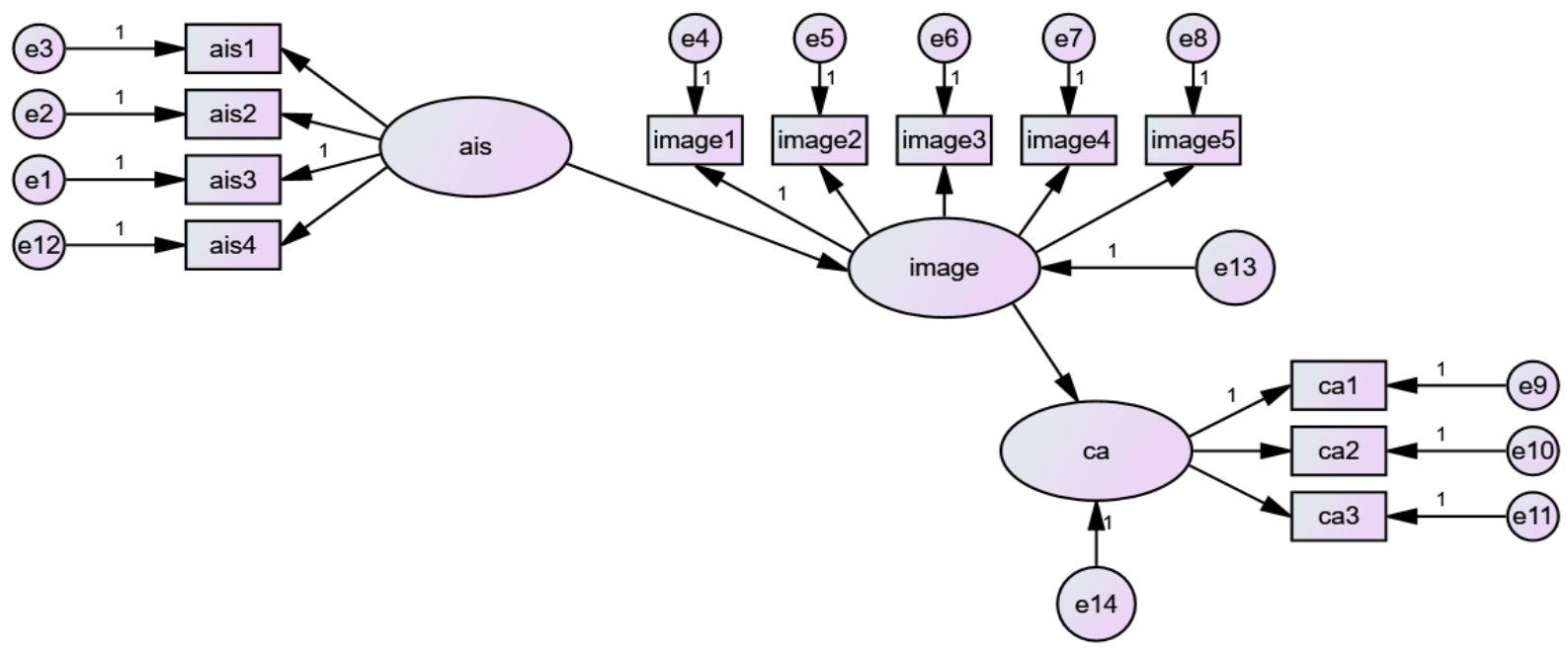

Figure 1

Structural Model of Research

\section{RESULTS AND DISCUSSION}

Before testing, the first evaluation was taken to the adequacy of the sample. The total sample at least must be 100 samples. This study has an estimated parameter value of 31points, this means the minimum required sample is 155 samples. Another index that can be used to test 
data adequacy is the Hoelter Index in text output [7]. The sample used in the research is 381 samples, this means the number of sample has exceeded from the minimum data adequacy limit. The value of Hoelter Index in text output is 397, means that the sample used is enough to be used in drawing the conclusion because the total sample is smaller than the Hoelter Index value.

Characteristics of respondents by sex majority of men $50.9 \%$. Age-based characteristics were dominated by respondents in the age range 21 - 25 years of $66.4 \%$. This shows that the majority of private college students in Kepulauan Riau province are not fresh graduates, and based on field observations and interviews it is found that in general they are workers in industrial companies. The number of respondents based on respondent program study is dominated by respondents in Information Systems 20.2\%. Characteristics of respondents based on the study period seen from the level of semester that is pursued by students, from obtained data of respondents are in semester 5 (five). They are the most respondents in this study 51.2\%. These results indicate that the majority of private university students in Kepulauan Riau province are workers in companies who are still young and have a tendency to choose the field of computer science.

\section{Validity}

A valid indicator can be seen through loading factor value. A model can be said to be fit if loading factor value is greater than 0.50. Table 1 shows that all variable indicators have a Critical Ratio (CR) greater than twice their Standard Error (SE) and have a probability value less than 0.05 . The results of this test indicate that these indicators have satisfied the requirements of construct validity.

Table 1.

Loading Factor value

\begin{tabular}{|ccc|c|c|c|c|c|}
\hline & & & $\mathrm{P}$ & S.E. & Critical Ratio & Loading Factor & Explanation \\
\hline ais1 & $<---$ & ais & 0.000 & 0.580 & 16.524 & 0.821 & Very strong \\
ais2 & $<---$ & ais & 0.000 & 0.059 & 17.712 & 0.886 & Very strong \\
ais3 & $<---$ & ais & Ref & Ref & Ref & 0.829 & Very strong \\
ais4 & $<---$ & ais & 0.000 & 0.052 & 16.500 & 0.741 & Very strong \\
\hline image1 & $<---$ & image & Ref & Ref & Ref & 0.767 & Very strong \\
image2 & $<---$ & image & 0.000 & 0.068 & 14.866 & 0.759 & Very strong \\
image3 & $<---$ & image & 0.000 & 0.064 & 16.402 & 0.831 & Very strong \\
image4 & $<---$ & image & 0.000 & 0.069 & 14.875 & 0.772 & Very strong \\
image5 & $<---$ & image & 0.000 & 0.069 & 14.786 & 0.753 & Very strong \\
\hline ca1 & $<---$ & ca & Ref & 0.009 & Ref & 0.994 & Very strong \\
ca2 & $<---$ & ca & 0.000 & 0.009 & 111.709 & 0.991 & Very strong \\
ca3 & $<---$ & ca & 0.000 & Ref & 118.78 & 0.993 & Very strong \\
\hline
\end{tabular}

\section{Reliability}

The approach used in assessing a measurement model is a construct reliability (CR) with values greater than or equal to 0.70 and Variance Extracted (AVE) with values greater than or equal to 0.50 [7]. 
Table 2 shows that the value of construct reliability (CR) is greater than 0.70 and the value of variance extracted (AVE) is greater than 0.50. The results of this test indicate that these indicators have met the reliability test requirements.

Table 2: Construct Reliability Value

\begin{tabular}{|ccc|c|c|c|c|}
\hline & & & $\begin{array}{c}\text { Loading } \\
\text { Factor }\end{array}$ & $\begin{array}{c}\text { Measurement } \\
\text { Error }\end{array}$ & $\begin{array}{c}\text { Construct } \\
\text { Reliability }\end{array}$ & $\begin{array}{c}\text { Variance } \\
\text { Extracted }\end{array}$ \\
\hline ais1 & $<---$ & ais & 0.821 & 0.326 & 0.892 & 0.674 \\
ais2 & $<---$ & ais & 0.886 & 0.215 & & \\
ais3 & $<---$ & ais & 0.829 & 0.313 & & \\
ais4 & $<---$ & ais & 0.741 & 0.451 & & \\
\hline image1 & $<---$ & image & 0.767 & 0.412 & 0.884 & 0.604 \\
image2 & $<---$ & image & 0.759 & 0.424 & & \\
image3 & $<---$ & image & 0.831 & 0.309 & & \\
image4 & $<---$ & image & 0.772 & 0.404 & & 0.985 \\
image5 & $<---$ & image & 0.753 & 0.433 & & \\
\hline ca1 & $<---$ & ca & 0.994 & 0.012 & 0.995 & \\
ca2 & $<---$ & ca & 0.991 & 0.018 & & \\
ca3 & $<---$ & ca & 0.993 & 0.014 & & \\
\hline
\end{tabular}

\section{Normality}

Normality testing is done by looking at the value of kurtosis value of the data used. Variables that have a skewness or kurtosis coefficient with a critical ratio of no more than \pm 2.58 indicate a normal distribution [7].

Table 3.

Value of Construction Reliability

\begin{tabular}{|ccccccc|}
\hline Variable & Min & max & skew & c.r. & kurtosis & c.r. \\
\hline ais4 & 2 & 5 & 0.011 & 0.084 & -0.566 & -2.257 \\
ca3 & 2 & 5 & -0.071 & -0.565 & -0.145 & -0.578 \\
ca2 & 2 & 5 & -0.154 & -1.224 & -0.177 & -0.707 \\
ca1 & 2 & 5 & -0.160 & -1.273 & -0.189 & -0.753 \\
image5 & 2 & 5 & 0.017 & 0.139 & -0.333 & -1.328 \\
image4 & 2 & 5 & -0.105 & -0.834 & -0.439 & -1.747 \\
image3 & 2 & 5 & 0.068 & 0.540 & 0.148 & 0.590 \\
image2 & 2 & 5 & -0.036 & -0.286 & -0.328 & -1.307 \\
image1 & 2 & 5 & 0.060 & 0.479 & -0.223 & -0.887 \\
ais1 & 1 & 5 & 0.075 & 0.599 & -0.167 & -0.665 \\
ais2 & 2 & 5 & -0.242 & -1.931 & -0.326 & -1.299 \\
ais3 & 2 & 5 & -0.058 & -0.460 & -0.412 & -1.643 \\
Multivariate & & & & & 15.642 & 8.328 \\
\hline
\end{tabular}

Table 3 shows that all data have a Kurtosis value and a Skewness value with a critical ratio of not more than \pm 2.58 . This means the data are allowed for analysis and continued [7]. This means that the data used in the study is normally distributed and very feasible for use in subsequent estimates. 
Relating with the results of the evaluation of data normality, factors such as outliers. Multi colinearity and singularity. Goodness of fit, modification indices and causality test have satisfied SEM condition.

Table 4.

Goodness of Fit Value to the Modified Model

\begin{tabular}{|l|l|l|l|}
\hline $\begin{array}{l}\text { Goodness of Fit } \\
\text { Measure }\end{array}$ & Indeks & Cut Off & Explanation \\
\hline $\begin{array}{l}\text { Chi-square of estimate } \\
\text { model }\end{array}$ & 62.965 & $>0.05$ & Fit model \\
\hline Probability Level & 0.060 & $\geq 0.9$ & Fit model \\
\hline $\begin{array}{l}\text { Goodness of Fit index } \\
\text { (GFI) }\end{array}$ & 0.975 & $\geq 0.9$ & Fit model \\
\hline $\begin{array}{l}\text { Adjusted Goodness of } \\
\text { Fit Index (AGFI) }\end{array}$ & 0.958 & $\geq 0.9$ & Fit model \\
\hline $\begin{array}{l}\text { Tucker-Lewis Index } \\
\text { (TLI) }\end{array}$ & 0.995 & $\geq 0.9$ & Fit model \\
\hline $\begin{array}{l}\text { Comparative Fit Index } \\
\text { (CFI) }\end{array}$ & 0.997 & $\leq 0.08$ & Fit model \\
\hline RMSEA & 0.030 & & \\
\hline
\end{tabular}

Table 4 shows that the results of the Goodness of Fit modulation model calculation gives a conformity index value that meets the recommended standard that is above the cut off value set. It can be concluded that the structural model is fit or has good and acceptable conformity.

The relation of causality between variables is shown in Table 5. The critical ratio (CR) value which is identical with the $t$ test in the regression analysis shows that all the regression coefficients are not significantly equal to zero. Thus, the hypothesis 0 which states that the regression coefficient equal to zero can be rejected and the causality relationship in the research model is acceptable.

Table 5.

Coefisien Between Variabel Ways

\begin{tabular}{|ccc|cccc|}
\hline & & & $\begin{array}{c}\text { Standardized } \\
\text { Estimate }\end{array}$ & C.R. & P & Explanation \\
\hline Image & $<---$ & ais & 0.210 & 3.760 & 0.000 & Significant \\
$\mathrm{Ca}$ & $<---$ & image & 0.286 & 5.479 & 0.000 & Significant \\
\hline
\end{tabular}

\section{Academic information system has a significant effect on image}

Table 5 shows that the regression between academic information system variables on the image of 0.210 with the critical ratio value of 3.760 and the probability value 0.000 . It states that academic information system variables significantly affect the image. The results of this study correspond to the results of a two-stage online survey conducted by Venkatesh et al. (2012) using data collected over four months: improving the performance of technology also enhances the reputation of a product so that consumers will continue to support the produced model [22].

\section{Image has a significant effect on competitive advantage}

Table 5 shows that the regression value between the image variables to the competitive advantage of 0.286 with the critical ratio value of 5.479 and the probability value 0.000 . It states that the image variables significantly affect the competitive advantage. The results of this 
study in accordance with research conducted Pfarrer et al. (2010) is a company that has garnered high reputation ("high reputation" companies) and celebrity companies (celebrity companies) are more likely to experience greater market rewards for positive surprises and smaller market penalties for negative shocks than firms other [14].

The study also found that academic information systems have an indirectly positive influence on competitive advantage of 0.060. This is in accordance with Huang's research results (2015), the company can take advantage of temporary competitive advantage as a result of market position to improve the position of resources and technological capabilities which can enhance their sustainable competitive advantage continuously [10].

\section{CONCLUSION}

This research resulted some findings that academic information system have significant effect to image and comply result of research of Venkatesh et al. (2012), the images have a significant effect on competitive advantage and comply with the results of research Pfarrer et al. (2010) as well as academic information systems have an indirect positive influence on competitive advantage and comply with Huang's research results (2015).

\section{SUGGESTION}

This study has some limitations because it does not cover all indicators of academic information system variables. Image and competitive advantage as proposed by previous researchers. Although the sample number meets the requirements for SEM. Larger samples are still needed to make generalizations. Beside that this research is located in Kepulauan Riau province in Indonesia in which the education field still in development. The next researcher is suggested to put more indicators of academic information system variables. Image and competitive advantage and enlarge the sample so that the result becomes more representative.

\section{References}

Abiad. F.. \& Bitter. F. (2009). Strategy and Competitive Advantage. Group. 1-4.

Al-Mamary. Y. H.. Shamsuddin. A.. \& Aziati. N. (2014). The Relationship Between System Quality. Information Quality. and Organizational Performance. International Journal of Knowledge and Research in Management \& ECommerce. 4(3). 7-10.

Alma. Buchari. (2013). Marketing Management and Marketing Services. Bandung. Alfabeta

Ardianto. Elvinaro. Soemirat. (2007). Basic of Public Relations. Bandung. Simbiosa Rekatama.

Assauri. Sofjan. (2013). Strategic Marketing: Sustaining Lifetime Customer Value. $1^{\text {st }}$ edition. Jakarta. Rajawali Pers. Besanko. D. Dranove. D. \& Shanley. M. (2013). Economics of Strategy. New York: John Wiley \& Sons.

Ferdinand, Augusty. (2014). Structural Equation Modeling. Semarang. BP Undip.

Hardcastle .E. (2011). Business Information Systems. Ventus publishing ApS.

Hasan.Y.. \& Shamsuddin.A.. \& Aziati .N. (2013). The Impact of Management Information Systems adoption in Managerial Decision Making: A Review. The International Scientific Journal of Management Information Systems. Vol.8 No.4. pp.010-017.

Huang, K.-F., Dyerson, R., Wu, L.-Y., \& Harindranath, G. (2015). From Temporary Competitive Advantage to Sustainable Competitive Advantage. British Journal of Management, 26(4), 617-636.

Lupiyoadi, Rambat, Hamdani, A. (2008). Marketing Management Services. Jakarta. SalembaEmpat

Petter. S \& McLean.E.R. (2009). A meta-analytic assessment of the DeLone and McLean IS success model: An examination of IS success at the individual level. Information \& Management. vol.46. pp. 159-166.

Petter .S.. \& DeLone. W.. \& McLean.E. (2008). Measuring information systems success: models. dimensions. measures. and interrelationships. European Journal of Information Systems. vol.17.pp. 236-263.

Pfarrer. M.. Pollock. T.. \& Rindova. V. (2010). A tale of two assets: The effects of firm reputation and celebrity on 
earnings surprises and Investors' reactions. Academy of Management Journal. 53(5). 1131-1152.

Porter, M. E. (2008). Competitive Advantage: Creating and Sustaining Superior Performance. Simon and Schuster.

Ramachandra. C.G. \&\& Srinivas .T.R. (2012). Acceptance and usage of management information system in small scale and medium to large scale industries. IEEE-International Conference on Advances in Engineering. Science and Management (ICAESM -2012) March 30.31.2012. 31-35

Raymond McLeod. jr. George P. Schell . (2007). Management Information System. $10^{\text {th }}$ edition. Jakarta. SalembaEmpat

Raymond. L. \& Bergeron. F. (2008). Project Management Information Systems: An empirical study of their impact on project managers and project success. International Journal of Project Management. 26 (2). 213- 220.

Robbins. S.P.. Coulter. M. (2007). Management. $9^{\text {th }}$ Edition. New Jersey. Pearson Education. Inc

Umar. H. (2011). Research Methods for Thesis and Business. $2^{\text {nd }}$ edition. Jakarta: Rajagrafindo Persada.

Urbach .N..\& Smolnik .S..\& Riempp.G. (2010). An empirical investigation of employee portal success. The Journal of Strategic Information Systems. Vol. 19.pp. 184-206.

Venkatesh, V., Thong, J., \& Xu, X. (2012). Consumer acceptance and user of information technology: Extending the unified theory of acceptance and use of technology. MIS Quarterly, 36(1), 157-178.

Wang, W., Lin, C.-H., \& Chu, Y.-C. (2011). Types of Competitive Advantage and Analysis. International Journal of Business and Management, 6(5), 100-104.

Yaser. H.A. Alina S. Nor Aziati. (2014) "The Meaning of Management Information Systems and its Role in Telecommunication Companies in Yemen." American Journal of Software Engineering. vol. 2. no. 2 pp.22-25. 